\author{
Asst. prof. dr. sc. Blerton Sinani ${ }^{1}$
}

Dr. sc. Dane Taleski

\title{
AN OVERVIEW OF THE JUDICIAL CONTROL OF STATE EXECUTIVE POWER
}

\author{
UDK: 342 \\ DOI: $10.31141 / z r p f s .2019 .56 .134 .1013$ \\ Review article \\ Primljeno: 1. II. 2019.
}

\begin{abstract}
Many analyses and international reports point out that there is a significant lack of judicial control over the state executive power in the Republic of North Macedonia. This article aims to analyze the deficiencies that contribute to the lack of control, and special attention is also devoted to the administrative judiciary as a basic external form of providing judicial control over the legality of the decisions of public authorities and their officials, in order to ensure objective legality, as well as the protection of individual rights of citizens against unlawful administrative acts and actions of public administration. The first part of the article focuses on challenges for judicial control of the executive government. It shows the results of semi-structured interviews conducted with 36 stakeholders such as judges and prosecutors about the limits to judicial control of the executive. The second part focuses on weaknesses and challenges of the administrative judiciary, and makes proposals on how to improve the administrative judiciary as a special type judiciary within the framework of the judicial system of the Republic of North Macedonia. Therefore, it presents a crucial illustration to detect the specific problems and to offer possible solutions.
\end{abstract}

Key words: judicial control; rule of law; democracy; administrative judiciary.

\section{INTRODUCTORY REMARKS}

In opening major international conference on judicial protection against executive in 1968, the president of the German Federative Constitutional Court defined the constitutional state as "a state in which the system of government is, at least in principle, understood as a system ruled by law". In such a system of government the essential features are "the subjection of the supreme power to the law, the separation of powers and the respect for the general, basic rights of man". 3

In their attempts to create a viable constitutional organization of state power, after the collapse of the socialist system the new East European democracies, began

1 Assistant Professor in the scientific-juridical area of Constitutional and Administrative Law at the Faculty of Law of the South East European University, Republic of North Macedonia, e-mail: blerton. sinani@seeu.edu.mk

2 The Foreign Policy Issues Adviser of the Prime Minister of the Government of the Republic of North Macedonia.

3 Gebhard Muller, Judicial Protection against the Executive, 1972, p. 2. 
to reinstall the universal values of the classical constitutional law (the principle of the rule of law, the separation and balance of state powers among the legislature, the executive and judiciary, the political pluralism as the fundamental basis for a free and democratic society, free market economy, etc.). These changes have also included the gradual opening of their internal legal systems and their adaptation to the dynamic developments in the international and European law. The protection of human rights has been of profound importance in this context and it has become one of the most critical conditions for the new democracies in their accession to the new regional and global legal order. ${ }^{4}$ In other words, the constitutional state resting on the ideology of the rule of law ${ }^{5}$ is characterized by the doctrine of tripartite state power, legal protection in a formal sense (the principle of legality), the legal protection of an individual by the state and other individuals, the concept of judicial discretion as a syllogistic form combining with a certain scale of legalism as general politics (spirit of law prevails to other arguments), and formal justice with the concept of formal equality before the court. ${ }^{6}$ The strongest expression of the link between constitutionalism and the separation of powers principle was made in the French Declaration of the Rights of Man, where it was asserted that: Any society in which the safeguarding of rights is not assured, and the separation of powers is not established, has no constitution. This is also the value underlying the classic principle of the separation of powers formulated by the French jurist, Montesquieu, in L'Esprit des Lois. If the same person or body exercised both legislative and executive powers, he argued, society would fear tyranny through the ruthless enforcement of oppressive laws by the authority which had enacted them. For the same reason, the judiciary should be independent of the legislature and executive. ${ }^{7}$ According to the doctrine of the separation of powers, each branch has different functions but each uses its power to police the limits of the others. As Montesquieu famously stated, "power must be checked by power". Indeed, it may be argued that essential values of law, liberty and democracy are best protected if the three primary functions of a law-based government are discharged by distinct state institutions. A lawmaker issues general rules, the executive implements the law and makes government policy, a judge acts

4 Petar Bačić, Zashtita Prava Čovjeka u Europskim Organizacijama, Split, 2007, p. 164; Oliver De Schutter, International Human Rights Law, Cambridge University Press, 2010, p. 23-25.

5 Emphasis will be placed on three related but separate ideas. First, statements of the rule of law embody a preference for orderly life within an organized community ("law and order"), rather than a situation of anarchy or strife in which there is no security for persons, their well-being or their possessions. Some stability in society is a precondition for the existence of a legal system. Second, the rule of law expresses a principle of fundamental importance - principle of legality, namely that government must be conducted according to law and that in disputed cases what the law requires is declared by judicial decision. Third, the rule of law refers to a body of opinion, both about what powers the government should have (for example, that the executive should have no power to detain without trial) and about the procedures (due process of law) to be followed when action is taken by the state (for example, the right to a fair hearing in criminal trials). - Anthony Bradley, Keith Ewing, Constitutional and Administrative Law, London, 2003, p. 95-96.

6 Arsen Bačić, Petar Bačić, Ustavna Demokracija i Sudovi, Split, 2009, p. 12.

7 Eric Barendt, An Introduction to Constitutional Law, London, 1998, p. 4-14; Arsen Bačić, Ustavno Pravo i Političke Institucije, Split, 2006, p. 212-215; Arsen Bačić, Principi Podjele i Jedinstva Vlasti u Jugoslaviji, Split, 1990, p. 11-69. 
as an independent referee by applying rules to a dispute. This threefold division of labour, between a legislator, an administrative official, and an independent judge, is a necessary condition for the rule of law in modern society and therefore for democratic government itself. Conversely, within the limits of its powers, each branch should be independent of the others. ${ }^{8}$ Separation of powers concerns the independence of the judicial system from other branches of government. The need for a separation of powers arises not only in political decision-making but also in the legal system, where an independent judiciary is essential if the rule of law is to have any substance. Namely, central to the rule of law in a modern democratic society is the principle that the judiciary must be, and must be seen to be independent of the executive. The proper constitutional relationship between the executive and the judiciary is that the judiciary will respect all acts of the executive within its lawful province, and that the executive will respect all decisions of the judiciary as to what its lawful province is. ${ }^{9}$

In the North Macedonia constitution of 1991 the separation of powers formed one pillar of the new edifice. The framers of the constitution intended that a balance of powers should be attained by vesting each primary function in a distinct organ. The North Macedonia constitution vests legislative power in Parliament (lawmaking), executive power (law-executing) in the Government and Head of State ("bicephalic"/two heads quality of the state executive branch - with prime minister and president) and judicial power (law-adjudicating) in the courts. ${ }^{10}$

The concept of separation of powers may mean at least three different things:

a) that the same persons should not form part of more than one of the three organs of government, for example, that ministers should not sit in Parliament;

b) that one organ of government should not control or interfere with the work of another, for example, that the executive should not interfere in judicial decisions;

c) that one organ of government should not exercise the functions of another, for example, that ministers should not have legislative powers. ${ }^{11}$

\section{SOME CONCEPTUAL ISSUES CONCERNING RULE OF LAW AND JUDICIARY}

The improvement of the judicial system and its functioning is a key prerequisite for the development of the Republic of North Macedonia as a democratic state of the rule of law and a multicultural society of citizens with equal rights and

8 John Alder, Constitutional and Administrative Law, London, 2007, p. 172.

9 Trevor Allan, Constitutional Justice: A Liberal Theory of the Rule of Law, London, 2001, p. 31-52; Eric Barendt, An Introduction to Constitutional Law, London, 1998, p. 14. 150-151

10 Светомир Шкариќ, Научно Толкување - Устав на Република Македонија, Скопје, 2014, p.

11 Anthony Bradley, Keith Ewing, Constitutional and Administrative Law, London, 2003, p. 84. 
freedoms and for its Euro-Atlantic integration. The development of a system of autonomous, independent and impartial judiciary and institutions that gravitate towards the achievement of its function of effective, quality and equitable justice is a central postulate of the principle of the rule of law and the humane and sustainable development of the Macedonian society as a community based on the right legitimized by respecting the highest universal civilization values. Moreover, the significance of the judiciary in a (liberal) democracy has been lauded countless times and thus it is believed to be a key element and an indicator of how well a democracy functions. On the other hand, the judiciary system is exceptionally important in the European integration process where, in line with the 'new approach' to the accession negotiations, it is one of the vital requirements for the future European Union membership. The judiciary is important in the enlargement process, but it is perhaps even more important in the period following the country's accession to the European Union because it will be crucial in application of European Union law in the Republic of North Macedonia. Due to the substantial significance of the judiciary, one of the key priorities of the Government of the North Macedonia is judiciary reform. To that effect, it recently adopted the 2017-2022 Judicial Reform Strategy, including an action plan. ${ }^{12}$

The court system of the Republic of North Macedonia follows two principles. The idea of specialization (horizontal structure) and the principle of hierarchy (vertical structure). The Republic of North Macedonia has different branches of jurisdiction with different powers:

- The ordinary judiciary (Basic Courts, ${ }^{13}$ Appellate Courts ${ }^{14}$ and the Supreme Court $^{15}$ ) decides civil and criminal cases;

- The administrative judiciary (Administrative Court and Higher Administrative Court) is exclusively designated for matters of administrative law such as deciding cases of all kinds of non-constitutional public law matters. Typical examples of actions brought before the general administrative judiciary are disputes arising from laws relating to building, traffic, trade and industry, social insurance, custom, education, protection of the environment, project planning and civil service matters; ${ }^{16}$

- The constitutional justice is installed outside of the state judicial power, and it is a specific autonomous state organ that has the duty to oversee the applicability of the constitution by other public authorities. It protects the constitutionality, legality, and the fundamental legal principles (values) of the constitutional order of the state. It also protects certain human rights and freedoms guaranteed

12 Denis Preshova, Judicial Reforms in the Republic of North Macedonia, Skopje, 2018, p. 3-4.

13 Basic courts are courts of first instance and are established to cover one or more municipalities.

14 Appeal courts are established to cover the territory of one or more basic courts and they act as courts of second instance to basic courts for civil and criminal matters.

15 Supreme Court is the highest court in North Macedonia and is competent to decide on extraordinary judiciary remedies in all kinds of public law and private law matters.

16 Кирил Чавдар, Кимо Чавдар, Коментар на Законот за Управните Спорови, Скопје, 2013, p. 18.; 64-66. 
and foreseen by the constitution. The constitutional court is the last instance permitted to perform a judicial review of the general normative acts (laws and by-laws) enacted by the state legislative and executive-administrative bodies. This is done by focusing on their formal and material (substantial) compatibility with the constitution and laws, and shall repeal or annul a law or any other regulation if it finds it to be unconstitutional (contra constitutionem) or unlawful (contra legem). ${ }^{17}$

One of the basic requirements for rule of law is an independent judiciary. Unlike the two political powers - legislative and executive - whose relationship rests on "checks and balances", the judicial branch has to be independent of any political influence. This can be ensured only by the constitution, as both legislative and executive branches are subjected to the constitution. So the supreme law must protect the judicial branch from the possibility of influence by the political powers. This means that the constitution itself must turn off any possibility of the legislative or executive violating the constitutionally guaranteed status of judiciary. An independent judiciary "maintains the balance" in the system of government, since its role is to prevent the abuse of authority. That is why James Bryce concluded long time ago that there is no better proof of the validity of a rule than the work of its judicial system. ${ }^{18}$

Rule of law failure underlines the main problems of democracy in North Macedonia. The third branch of government seems unable to live up to its authority, i.e. to implement its powers from a practical point of view. This has been well elaborated in many international reports. The lack of implementation of laws as well as budgetary constraints are some problem areas identified in various reports about the judiciary in North Macedonia. For example, the Priebe Report ${ }^{19}$ notes that, "The country possesses a comprehensive set of rules which, if fully observed, should

17 See: Светомир Шкариќ, Уставно Право, Скопје, 2009, p. 699-719.

18 Džems Brajs, Savremene Demokratije, Beograd, 1933, p. 88.

19 The Republic of North Macedonia: Recommendations of the Senior Experts' Group on systemic Rule of Law issues relating to the communications interception revealed in Spring, 2015, p. 9 
Asst. prof. dr. sc. Blerton Sinani i dr. sc. Dane Taleski: An overview of the judicial control of state... Zbornik radova Pravnog fakulteta u Splitu, god. 56, 4/2019, str. 1013-1029

generally ensure a proper functioning of the judicial system to a high standard". ${ }^{20}$ Without a doubt, this is an often-heard statement in North Macedonia. Namely the idea that the problem is not in the normative legal framework, but in the applicative aspect, i.e. in the implementation in practice. However, this puts into question the adequacy of laws. Are they implementable at all? An answer to the questions of the implementation of laws as well as the independence of the judiciary may partially lie in budgetary constraints. As the U.S. State Department report states, "The inadequate funding of the judiciary continued to hamper court operations and effectiveness. A number of judicial officials accused the government of using its budgetary authority to exert control over the judiciary". ${ }^{21}$

However, the judiciary is not simply hampered by the lack of independence or budget, but also by the lack of public trust among citizens. Two studies, one supported by IRI (International Republican Institute) and the second conducted within Network 23, provide data which show a deep mistrust in the judiciary and its various institutions. The IRI survey shows that a majority of the citizens interviewed do not trust the courts, nor the Public Prosecutors based on their actions in the past year. $^{22}$ The analysis within Network 23 notes a lack of trust in the Judicial Council, particularly among the Albanian ethnic population $(63 \%) .{ }^{23}$ The lack of trust in citizens hinders the legitimacy of the courts as well as the perception of

20 EU should build upon its own positive example of addressing state capture in North Macedonia - Let us recall how the official EU reports missed the scope of Rule of Law collapse in North Macedonia before the so called political bombs went off in 2015. The bombs refer to disclosure of illegally intercepted telephone calls, which unveiled numerous corruptive practices of the ruling party, including interfering with the work of the judiciary, manipulating election process, tightening the grip over the media and releasing security services from democratic oversight. The bombs lead the political crisis in Macedonia to its peak in 2015, making it clear to the EU that it must act swiftly and effectively. Along with diplomatic mediation between political actors in Macedonia, the EU gathered a group of independent experts, lead by a retired European Commission director Reinhard Priebe and tasked to identify systemic Rule of Law issues in the country. This endeavour resulted in the so called Priebe report. Independent experts from EU member states were more frank in providing diagnosis and they weren't trapped in overly formalized structure of EU reports. Nevertheless, the fact that the Report was commissioned and published by the European Commission provided it with great authority. The Priebe Report identified the security sector as an important lever of state capture. It pointed to power concentration in one civilian intelligence service in Macedonia, operating without oversight. Responsible authorities hadn't used their control and oversight powers, because they were politic-sized or intimidated, or otherwise sabotaged. Although democratic civilian control looked good on paper, it has failed in practice. Well written laws were not enough. Priebe's team explained how specific problems it analyzed in several areas - judiciary, independent institutions, media, elections and interception of communications - have in fact common sources. Beside insufficient transparency of public affairs and widespread political corruption, one of the key causes was the absence of constructive political dialogue. The vicious circle of polarization, politicization and fear rendered democratic mechanisms paralyzed and led to state capture. The Report offers an overall picture, doesn't beat around the bush and offers concrete recommendations. These were transposed into the Urgent Reform Priorities for North Macedonia and the EU facilitated a special agreement between ruling and opposition parties. The European Commission managed to commit the Macedonian political actors to their implementation, by announcing its own monitoring of the reforms and turning them into a pre-condition for the country's progress towards accession. - https://europeanwesternbalkans.com/2019/02/08/priebereport-state-capture-western-balkans/

21 US State Department Macedonia Human Rights Report, 2014, p. 6

22 Survey of Public Opinion in Macedonia, Skopje, 2015, p. 31

23 Institute for Human Rights, Analysis of independence of the Judicial Council of Republic of Macedonia-Aspirations and Challenges, Skopje, 2015, p. 27. 
their reliability by the citizens. This might partially serve to explain why there is no public pressure on judiciary reform. A lack of preparation of laws and their hasty implementation is another serious problem that has been noted in various reports. For example, the European Commission Progress Report noted that the law for establishing the Council for Determining Facts is a, "Further blow to a profession which is already under siege" ${ }^{24}$ The enactment of this law points out the persisting challenges that exist for independence of the judiciary in North Macedonia. Regardless of numerous negative comments the government formed the Council for Determining Facts in a hasty procedure. However, it was not operational until March, 2016. Why is the judiciary not able to carry out its constitutional duty and act as a third specific branch of government? This article aims to answer that question. In doing so it assumes a two-step process. In the first part it outlines results from an empirical study that enlighten the limits of the judiciary's control of the executive. In the second part it takes a closer look at the administrative justice which has an essential function to protect the citizens against unlawful acts of public bodies. We aim to explain the major weaknesses of the judiciary in its inability to control the executive, and then we will proceed in the area of the administrative justice as the external form and the most favorable manner for control of legality over administrative acts and actions of the state executive-administrative power.

\section{ANALYSIS: CHALLENGES FOR JUDICIAL CONTROL OF THE EXECUTIVE}

The first part of this paper utilizes parts of an empirical study conducted with 36 semi-structured expert interviews conducted during the months of December, 2015 and January, 2016. ${ }^{25}$ This is not a representative sample of the applicable stakeholders. However, it is a very high number of experts' interviews and there is a high saturation in the answers. Most of the interviews (14 which is $38.9 \%$ of the total) were done with judges and prosecutors. Interviewees included judges from basic courts all the way to the Constitutional Court and prosecutors from different levels. Interviews were also done with appropriate members of parliament (5) such as the Deputy Speaker of Parliament and members of legislative committees. Also interviews included the government (6) such as acting and previous Ministers of Justice and high ranking public administration officials. Finally interviewed were interested members of the public (11) such as applicable NGOs, journalists, university professors and international actors. The experts interviewed included former and acting stakeholders whose experience with the judiciary ranges between 5 and 40 years. Respondents were asked to answer closed questions which evaluated the independence of the judiciary, and open questions which focused on the

24 European Commission Progress Report 2015 for the Former Yugoslav Republic of Macedonia, p. 52 .

25 Detailed results of the research are published in Dane Taleski et alia, Improving the system of checks and balances in the Republic of Macedonia, Skopje, 2016. 
challenges and accomplishments of reforms. The data was analyzed by comparing the means with Cronbah's Alpha Test for reliability of results. ${ }^{26}$ The respondents gave relatively low grades for the functioning of judicial institutions. The results are shown below in table 1 . The answers are an assessment of the judicial control of executive and judicial independence, and are an estimation of the work in civil cases. It is somewhat surprising that the Judicial and Prosecutors' Councils, the new institutions set up to guarantee the independence of the judiciary from political interference, received the lowest grade. The Judicial Academy got a relatively higher grade which means almost a 3 and it was generally seen as the most positive step towards the improvement of the judiciary both in its efficiency and its quality. As one respondent stated, "The Academy provides a positive step towards the longterm improvement of the judiciary."

Table 1. Grading the work of the judicial institutions, on a scale a scale from 1 (worst) to 5 (best)

\begin{tabular}{|c|c|c|c|c|c|}
\hline $\mathrm{N}=35$ & 1 & 2 & 3 & 4 & 5 \\
\hline Courts & & $\begin{array}{c}2.42 \\
(0.80)\end{array}$ & & & \\
\hline Prosecutors & & $\begin{array}{c}2.34 \\
(1.02)\end{array}$ & & & \\
\hline Judicial Council & $\begin{array}{c}1.78 \\
(0.83)\end{array}$ & & & & \\
\hline Public Prosecutors & $\begin{array}{c}1.77 \\
\text { Council }\end{array}$ & & & & \\
\hline Judicial Academy & & $\begin{array}{c}2.97 \\
(0.87)\end{array}$ & & & \\
\hline
\end{tabular}

Cronbah's Alpha: 0.79, standard deviation in parenthesis

The independence and accountability of the judiciary was supposed to be strengthened with the introduction of the Judicial and Public Prosecutor's Councils. However, in practice the councils seem to play somewhat a different role. Respondents gave a very low score for their functioning, and other research corroborates the existing weaknesses ${ }^{27}$ For many of our respondents the respective councils represent an intermediary instrument for the executive to control judges and prosecutors even though some measures were undertaken to increase their independence such as the

26 Cronbah's Alpha is a statistical measure which shows the correlation within a set of answers. It is a standardized test when analyzing and comparing means to show internal consistency and reliability of the answers. The test value ranges from 0 to 1 . Values above 0.5 are acceptable; however higher values designate higher consistency and reliability.

27 Institute for Human Rights, Analysis of independence of the Judicial Council of Republic of Macedonia - Aspirations and Challenges, Skopje, 2015, p. 27. 
Minister of Justice no longer has the right to vote in the Judicial Council. Judges and prosecutors elect the majority of the members in the councils. The elected members represent the geographical and hierarchical set up of the courts and prosecutor's office. In general, the respondents considered the independence of the judiciary to be in the decline, and noted that this was mostly due to the presence of political interference. As indicative examples of this is the respondents pointed to cases where high ranking government officials sued journalist or political opponents for libel and defamation and to cases where opposition politicians are put on trial, which are seen as cases portraying selective justice. Furthermore, when asked about the challenges of the judiciary most of the respondents noted that political interference was the greatest obstacle. Indeed, the European Commission Progress Report also notes that, "The extent of previously suspected political interference in both the appointment of judges and the outcome of court proceedings was confirmed by the content of the intercepted communications". ${ }^{28}$ Serious concerns about the lack of judicial control of the executive, or to put it precisely, the belief that the executive controls the judiciary provide a very negative view about the entire judicial system. Even though on average the judicial system has improved compared to previous years, the handling of sensitive and politically charged cases creates an impression of a failing rule of law. Such cases present a minority of all cases; however, they show precisely what the state of judicial control of the executive is. Almost all of our respondents, across categories, believed that the executive controls the judiciary. Respondents were asked to name an example, the first that comes to mind, of judicial control of executive. Almost none of the respondents could point out an example of judicial control over the executive. Some even claimed that the judiciary can't control the executive, because the judiciary was there to enforce the laws, while the executive together with the legislative enacted the laws, while one respondent noted that the way that the system in North Macedonia is built simply does not allow for judiciary control over the executive. This shows that many of the relevant stakeholders, including judges and prosecutors, do not see the judiciary as an equal and independent branch of power, but as being subordinated to the executive. Very few of the respondents pointed out to cases where acting politicians were held accountable in a court of law. These were mainly corruption cases against state secretaries, some heads of sectors and local government officials. There have been no cases when acting high level politicians were taken to court. On the other hand, there are cases against former high-level politicians, which one of our respondents labeled as "revenge cases", namely former executives being charged by the new governing powers to assert strength. ${ }^{29}$

28 European Commission Progress Report 2015 for the Former Yugoslav Republic of Macedonia, p. 52.

29 Dane Taleski et alia, Improving the system of checks and balances in the Republic of Macedonia, Skopje, 2016, p. 28. 
Table 2. Grading the independence of the judiciary

\begin{tabular}{|c|c|c|c|c|c|}
\hline $\mathrm{N}=34$ & 1 & 2 & 3 & 4 & 5 \\
\hline Judiciary & & $\begin{array}{c}2.03 \\
(0.75)\end{array}$ & & & \\
\hline Judicial Council & $\begin{array}{c}1.53 \\
(0.75)\end{array}$ & & & & \\
\hline $\begin{array}{c}\text { Public Prosecutors } \\
\text { Council }\end{array}$ & $\begin{array}{c}1.5 \\
(0.75)\end{array}$ & & & & \\
\hline $\begin{array}{c}\text { Adequacy of Judicial } \\
\text { Budget }\end{array}$ & & $\begin{array}{c}2.68 \\
(1.06)\end{array}$ & & & \\
\hline $\begin{array}{c}\text { Judicial Control of } \\
\text { Executive }\end{array}$ & $\begin{array}{c}1.74 \\
(1.05)\end{array}$ & & & & \\
\hline
\end{tabular}

Cronbah's Alpha: 0.62, standard deviation in parenthesis

The results show that there is very low independence of the judiciary. There is some financial independence. The adequacy of the judicial budget has a mean score of 2.68, which is the highest compared to the others. The independence of the overall judiciary has a mean score of 2 , while the independence of the councils and the possibility for judicial control over the executive were graded as lower. Respondents were asked to grade to what extent different factors limit the independence of the judiciary, on a scale for 1 (lowest) to 5 (highest). Majority of the respondent pointed out to political influences as the main impediment for the independence of the judiciary. The results, with a relevant Cronbah's Alpha Test, are shown in table 3.

Table 3. What is limiting the independence of the judiciary

\begin{tabular}{|c|c|c|c|c|c|}
\hline $\mathrm{N}=32$ & 1 & 2 & 3 & 4 & 5 \\
\hline Bad laws & & $\begin{array}{c}2.31 \\
(1.2)\end{array}$ & & & \\
\hline Political influences & & & & 4.47 & \\
\hline $\begin{array}{c}\text { Incompetent judges } \\
\text { and prosecutors }\end{array}$ & & & 3.19 & & \\
\hline $\begin{array}{c}\text { Lack of capacities } \\
\text { (space) }\end{array}$ & & 2.34 & & & \\
\hline $\begin{array}{c}\text { Bad technical } \\
\text { resources }\end{array}$ & & $\begin{array}{c}(1.23) \\
(1.21\end{array}$ & & & \\
\hline Bad administration & & 2.5 & & & \\
\hline Low salaries & & 2.59 & & & \\
\hline
\end{tabular}

Cronbah's Alpha: 0.55, standard deviation in parenthesis 
It is not surprising that political influences are the main factor. Other research, done in North Macedonia in 2015 corroborates the findings. According to an IRI (International Republican Institute) nation-wide survey a majority of the respondents considered that courts are susceptible to political influences for example, $22 \%$ of respondents said "fully susceptible" and 33\% said "rather susceptible". ${ }^{30}$ However, it is somewhat surprising that the incompetence of judges and prosecutors comes as the second most influential factor that limits the independence of the judiciary, with a mean score of 3.19. The other factors were seen as having less of an influence and approximately being on the same level. These results point out the doubts about the quality of human resources in the judiciary. They also reflect deep mistrust in the personal capacities of individual judges. ${ }^{31}$

\section{THE ADMINISTRATIVE JUSTICE: CHALLENGES AND PERSPECTIVES}

A judicial review, sometimes called a supervisory jurisdiction, has the administrative justice power to police the legality of decisions made by public bodies. Usually an accommodation must be struck between competing aspects of the separation of powers. On one hand the rule of law has been said to require that the legality of government action must be subject to review by independent and impartial administrative judiciary. The principles of judicial review give effect to the rule of law. They ensure that administrative decisions will be taken rationally in accordance with a fair procedure and within the powers conferred by law. Both the separation of powers and the European Convention on Human Rights require the courts to check misuse of power by the executive, but also to avoid trespassing into the political territory of the government. Judicial review is regarded as a last resort method of challenge and there are procedural barriers intended to prevent this from being too easily taken up. The constitution therefore ensures that the executive power is subjected to independent judicial control as an external control of legality of its decision-making in administrative matters. ${ }^{32}$

The judicial review of administrative acts and actions is an essential process if the rule of law is to be observed in a modern democracy. ${ }^{33} \mathrm{~A}$ state based on the rule of law implies the capacity of citizens to submit administrative actions to judicial control. Moreover, judicial control appears to be an indispensable instrument to enhance the quality of administrative action and ensure good governance. It is also fundamental for international economic exchanges, since security of trade and

30 Survey of Public Opinion in North Macedonia, Skopje, 2005, p. 57.

31 Dane Taleski et alia, Improving the system of checks and balances in the Republic of Macedonia, Skopje, 2016, p. 30

32 See: Peter Leyland, Gordon Anthony, Administrative Law, London, 2016, p. 186-188.

33 Anthony Bradley, Keith Ewing, Constitutional and Administrative Law, London, 2003, p. 695. 
investment depends on public decision-making bodies being subject to effective means of oversight and redress. ${ }^{34}$

The power of national competent court conferred by law to exercise judicial control over legality of individual administrative acts of the executive-administrative branch of state power, and to annul administrative acts which are contrary to the provisions of the certain law is called administrative judicial review. In the European tradition, judicial protection by administrative judiciary in principle has two different objectives. On the one hand the legal protection of individual rights and legal interests of citizens against unlawful administrative acts and actions of state executive-administrative power and on the other hand the surveillance of the legality of administrative acts in order to ensure objective legality. ${ }^{35}$

The role of the administrative justice is not an extension of the administration with the aim of a comprehensive objective control, but the protection of the individual rights against public authorities. It is a guarantor of effective protection of subjective rights and legal interest of the individual and citizen as a central segment while protecting public interest and necessity for democratic society. Furthermore, it should be noted that administrative justice is a bastion of the rule of law when it comes to the application of law by the executive-administrative branch of state power of the certain state. Administrative justice is by no means hostile in relation to the power apparatus of state administration. On the contrary, administrative justice can only strengthen it by giving legitimacy to the challenged decisions. On the other hand, administrative justice is a guarantor of citizen's right to a public administration at its best, and that is why judges should be up to the task of the court while applying the administrative court proceeding (judicial review proceeding) in concrete cases in practice which is regulated by the Law on Administrative Disputes. From this result the principal conclusion that administrative justice is an instrument for legally protecting human rights infringed upon by a public authority, as well as an outstanding method of providing lawfulness in public administration activity. ${ }^{36}$

The administrative dispute as a judicial protection of the citizens' rights from unlawful acts and actions of the administration in the Republic of North Macedonia has a long tradition. It was introduced for the first time in the Law on Administrative Disputes in 1952, supplemented by a new Law on Administrative Disputes in 1977, and the third and last Law on Administrative Disputes adopted in 2006 according to which a separate specialized administrative judiciary was established in the country. This Law was amended in 2010 with provisions for the establishment of a Higher Administrative Court without stipulating provisions for conducting proceedings before this Court. The biggest problems that citizens face in the administrative-legal relations with the state (with the public authorities according to the terminology

34 Jean-Marie Woehrling, Judicial Control of Administrative Authorities in Europe, Hrvatska Javna Uprava, god. 6. (2006.), br. 3,p. 36.

35 See: Pero Krijan, Komentar Zakona o Upravnim Sporovima, Zagreb, 2006, p. 24-25; Ivo Borković, Upravno Pravo, Zagreb, 2002, p. 128; 483.

36 Nikola Stjepanović, Upravno sudstvo kako sredstvo zaštite zakonitosti, Beograd, 1976. 
of the Law on the General Administrative Procedure) include: firstly, regarding the length of the overall administrative procedure (administrative procedure before public authorities, followed by an administrative dispute), and secondly, in failing to enforce the decisions of the administrative judiciary. The length of the procedure consisting of five instances of which two before the state administration bodies called public bodies and three in the framework of the administrative dispute before the Administrative Court, the Higher Administrative Court and declaratively before the Supreme Court of Republic of North Macedonia, make the protection of citizens' rights delayed and expensive. What can be noted from the research conducted by the academic community and non-governmental organizations, as well as the reports drawn up by the experts within IPA (The Instrument for Pre-Accession Assistance) 2007 project is the following: ${ }^{37}$ the protection of the rights of the citizens is stalled, the same judgments of the Administrative Court which were previously repealed and remitted for a new trial are upheld, which for the party means only a waste of time and increased expenses. It was found out that it is unnecessary for the public authorities to be represented in the administrative dispute against them by the State Attorney General's Office. Namely, under the 2015 Law on General Administrative Procedure, the official who conducted the administrative procedure is obliged to also terminate it or, in other words, to adopt and sign the decision. $\mathrm{He} /$ she replies to the complaints against his/her decision before the second instance state commission which decides on appeals in administrative proceedings. If a citizen, in the capacity of a party, initiates an administrative dispute against the second instance state commission's decision, there is no logical or legal justification for the State Attorney General to represent the public authority in such an administrative dispute. Failure to rule in full jurisdiction by judges of the Administrative Court is an additional problem for citizens creating a ping-pong effect in the protection of their rights. On the one hand, they have received from the Administrative Court a judgment in their favour, but on the other hand, instead of solving their problem on the merits, the judgment refers them back to another administrative procedure before the state administration authorities. In this way, citizens have obtained court justice de jure or on paper, but not de facto or for real. ${ }^{38}$ This problem is a consequence of the failure of the respondent bodies of state administration to submit the files during the administrative dispute which is why the Administrative Court cannot decide meritoriously in a dispute of full jurisdiction. The judgments of the Administrative Court repealing the decisions of the state administration authorities and remitting them for redress with concrete court instructions are not enforced by the state administration authorities as they again make a decision with the same content as the previous repealed decision. The Administrative Court faces a problem of non-enforcement of its judgments, a phenomenon that has not

37 "Capacity building of the administrative judiciary in the Republic of Macedonia in the face of the challenges for achieving European standards" - "Ss. Cyril and Methodius" University Skopje 2015; and IPA 2007 Project "Support for more efficient, effective and modern operation and functioning of the Administrative Court" Annex 6, December 2011.

38 Strategy for Reform of the Judicial Sector for the Time Period 2017-2022, Skopje, 2017, p. 25. 
been observed in any country in which the principle of the rule of law is applied consistently. The disputes from the administrative contracts, although explicitly defined in the Law on Administrative Disputes of 2006, and since 2015 also in the Law on General Administrative Procedure as the competence of the Administrative Court, are still mostly decided in the regular courts, meaning that in this area also there is a total discrepancies in the application of the law. The conditions for the operation of the Administrative Court (spatial, technical and personnel) are reduced to a minimum and completely incompatible with a court of this rank which handles the most significant disputes against the state. Because of all the negative findings stated above, it is necessary to draft a comprehensive analysis of the situation in the administrative judiciary the results of which should be the basis for future legal changes in this matter. The State Attorney's Office does not need to represent the public authorities in administrative disputes, given the new decisions in the Law on General Administrative Procedure according to which the official conducting the procedure also adopts the final administrative act. Hence, the official representing the public authority will defend his/her decisions in an administrative dispute. It is necessary to take measures for consistent application of the mandatory court judgments and to foresee a way to determine how many of the final judgments were enforced within the legally prescribed period of 30 days. This is one of the European principles outlined in the Protocol. The Law on Administrative Disputes should contain provisions for sanctioning public authorities which do not submit to the Administrative Court the necessary documents required for proper conduct and conclusion of the administrative dispute. Specific training of administrative judges is required for the proper adjudication of disputes arising from administrative contracts which will be conducted by national and international experts. The number of trials with public hearings should increase. The Law of Administrative Disputes should be aligned with the 2015 Law on General Administrative Procedure. There is a need for supplementing and specifying certain data within the Annual Reports on the work of the Administrative Court, such as how many decisions were made in disputes in full jurisdiction, how many decisions were made after a previously held oral hearing, how many of the decisions were made by a single judge, that is, to specify the ground on which the decisions taken were upheld. It is necessary to improve the spatial and technical conditions for the work of the Administrative Court in order for administrative judges to perform their work more efficiently, as well as to acquire the necessary dignity and integrity. ${ }^{39}$

\section{CONCLUSION}

The article starts from the factual situation of the judiciary that is well noted in several international reports. The findings suggest that the judiciary faces serious impediments to act as the third independent branch of government and

39 Strategy for Reform of the Judicial Sector for the Time Period 2017-2022, Skopje, 2017, p. 25-26. 
that it not able to fully control the executive. These findings were corroborated in the empirical results of the study that the article utilizes. The results of the study suggest that various stakeholders within the judiciary give low grades for the functioning of judicial institutions in practice. Furthermore, there seems to be a wide range of opinion that the independence of the judiciary is very low. For many of our respondents, the Judicial and Prosecutor's Councils represent an intermediary instrument for the executive to control judges and prosecutors, even though some measures were undertaken to increase their independence. In general, the respondents considered the independence of the judiciary to be in the decline, and noted that this was mostly due to the presence of political interference. As indicative examples of this is the respondents pointed to cases where high ranking government officials sued journalist or political opponents for libel and defamation and to cases where opposition politicians are put on trial, which are seen as cases portraying selective justice. Furthermore, when asked about the challenges of judiciary most of the respondents noted that political interference was the greatest obstacle. Even though on average the judicial system has improved compared to previous years, the handling of sensitive and politically charged cases creates an impression of rule of law failure. Respondents were asked to name an example, the first that comes to mind, of judicial control of executive. Almost none of the respondents could point out an example of judicial control over the executive. Some even claimed that the judiciary can't control the executive. This shows that many of the relevant stakeholders, including judges and prosecutors, do not see the judiciary as an equal and independent branch of power, but as being subordinated to the executive. Majority of the respondent pointed out to political influences as the main impediment for the independence of judiciary. The second reasons were the incompetence of judges and prosecutors. The other factors were seen as having less of an influence and approximately being on the same level. These results point out the doubts about the quality of human resources in the judiciary. One need to point out that these conclusions came from a study that was done in December, 2015 and January, 2016. From a time-perspective they need to be taken with a grain of salt even though they are very indicative for the improvements and reforms that need to be outline in the future to have a functional judicial system.

The improvement of the judicial system and its functioning are a key assumption for the development of the Republic of North Macedonia as a democratic state of law and a multicultural society and its Euro-Atlantic integration. In that sense, with the adoption of the Strategy for the reform of the judicial sector for the time period 2017-2022 (with an Action Plan), several main goals were set that represent a phased overcoming of the identified weaknesses in the judiciary, its placement on the path of European and international standards and its functioning as the main pillar of the democratic state of law, among which the attempt to remove from the legal order legal solutions that blocks the realization of the function of judicial control over the legality of the actions of the state executive-administrative power and the reform of the administrative judiciary for the purpose of efficient realization of its function of control over the acts of the state executive-administrative power. 
From a material-functional point of view, the administrative justice/judiciary is not a new legal category, more precisely the administrative dispute as regular and systematic form of judicial control over the legality of administrative acts of the state executive-administrative power in the Republic of North Macedonia, for the sole reason that it dates back to 1952 and there is judicial practice and legal tradition of more than 60 (sixty) years. On the other hand, from a formal-organizational perspective, the administrative justice/judiciary presents a completely innovative segment within the composition of judicial system of the Republic of North Macedonia, that represent a specialized court instance that should guarantee legal certainty and regularity of decision-making in administrative matters i.e. in all administrative-legal areas. The foundation of administrative judiciary is a part of the reforms in the judiciary planned under the Judicial Reform Strategy adopted by the Ministry of Justice of the Republic of North Macedonia in 2004, for the purpose of establishing an independent and efficient judiciary. The Administrative Judiciary is competent for adjudicating in administrative disputes within the legal system of the Republic of North Macedonia. Administrative judiciary in North Macedonia is being provided through two court instances - the Administrative Court (examining suits on decisions of the state administrative bodies) and the Higher Administrative Court (examining appeals against decisions of the Administrative Court). Therefore, the Higher Administrative Court decides as second and last court instance on appeals as a regular legal remedy against decisions of the Administrative Court of first instance. The efforts of the Administrative Judiciary to deal with its considerable case load and to continuously reduce the backlog of pending cases with the available number of judges, court advisors and supporting staff as well as with the current legal provisions deserve full recognition. Nevertheless, a reform of the administrative judiciary is indispensable for the following reasons: firstly, the current Law on Administrative Disputes is not in line with EU-standards (acquis communautaire), thus being an obstacle on North Macedonia's way to accession to the European Union; secondly, the current Law on Administrative Disputes lacks provisions for more effective court proceedings. The standards from Article 6 of the European Convention of Human Rights and Fundamental Freedoms (ECHR) require a two-tier system of administrative justice with administrative dispute of full jurisdiction, public hearing, the right to appeal to the higher court, and the protection of issuing administrative decisions within a reasonable time. For now, North Macedonia has a two-tier system of administrative justice, at least formally in line with the standards of the Convention.

Under the current Law on Administrative Disputes of the Republic of North Macedonia of 2006 the Administrative Court in principle has only cassatory powers. This means that if the court concludes that an administrative body illegally refuses to issue an administrative act in favour of a citizen (for example, building permit), it can only repeal the challenged act (cassatory decision) and return the case to the administrative body (article 36 paragraph 2 Law on Administrative Disputes). Apart from a few exceptions (article 40 Law on Administrative Disputes), the court is not competent to order an administrative body to render the requested administrative 
act (reformatory decision). As a result, some cases come back to the court again, some even several times, which leads to a so-called "ping-pong effect". This "pingpong effect" is one of the main problems of the administrative judiciary because it prolongs the overall duration of proceedings. This term comprises the period from the first application before an administrative body until the rendering of a final court decision. From the view of the citizen or an investor that is the decisive period. In addition to that, it is the overall duration of proceedings that is decisive for the question whether the duration of proceedings (delayed justice is not relay justice since it might cause distrust in the existence of justice itself and of legal protection in general) violates the European Convention on Human Rights (article 6). The reduction of the "ping-pong effect" will result in a shorter duration of proceedings and in a reduction of the number of incoming cases. Because of these effects, the step from a mere cassatory to a reformative system is one of the most important steps in the legislative reform of administrative court proceeding (judicial review proceeding) of the Republic of North Macedonia.

\section{PREGLED SUDSKE KONTROLE DRŽAVNE IZVRŠNE VLASTI}

Mnoge analize i međunarodna izvješća ukazuju na to da u Republici Sjevernoj Makedoniji postoji značajan nedostatak sudske kontrole nad izvršnom vlašću države. Ovaj članak ima za cilj analizirati nedostatke koji doprinose nedostatku kontrole, a posebna se pažnja posvećuje i upravnom sudovanju kao osnovnom vanjskom obliku pružanja sudske kontrole zakonitosti odluka državnih tijela i njihovih službenika, kako bi se osigurala objektivna zakonitost, kao i zaštita pojedinačnih prava građana od nezakonitih administrativnih akata i radnji javne uprave. Prvi dio članka fokusiran je na izazove koji se pojavljuju u sudskoj kontroli izvršne vlasti. Iznose se rezultati polustrukturiranih intervjua provedenih sa 36 sudionika, poput sudaca i tužitelja, o ograničenjima sudske kontrole izvršne vlasti. Drugi dio se fokusira na slabosti i izazove upravnog sudovanja, te daje prijedloge kako poboljšati upravno sudovanje kao posebne vrste sudovanja u okviru pravosudnog sustava Republike Sjeverne Makedonije. U tom smislu nalazi predstavljaju ključnu ilustraciju za otkrivanje specifičnih problema i za pružanje mogućih rješenja.

Ključne riječi: sudska kontrola, vladavina zakona, demokracija, upravno pravosuđe 